\title{
Distinct Mechanisms for Regulation of the Interleukin-8 Gene Involve Synergism and Cooperativity between C/EBP and NF-kB
}

\author{
BERND STEIN ${ }^{1} \dagger$ AND ALBERT S. BALDWIN, JR. ${ }^{1,2 *}$ \\ Lineberger Comprehensive Cancer Center ${ }^{1}$ and Department of Biology, ${ }^{2}$ University of North Carolina at \\ Chapel Hill, Chapel Hill, North Carolina 27599
}

Received 25 June 1993/Returned for modification 3 August 1993/Accepted 13 August 1993

\begin{abstract}
The interleukin-8 promoter is transcriptionally activated by interleukin-1, tumor necrosis factor alpha, phorbol myristate acetate, or hepatitis B virus $X$ protein through a sequence located between positions -91 and -71. This region contains an NF-kB-like and a C/EBP-like binding site. We show here that several members of the NF-kB family, including p65, p50, p52, and c-Rel, can bind to this region, confirming an authentic NF-אB binding site in the interleukin-8 promoter. Further, C/EBP binds only weakly to the interleukin-8 promoter site. Electrophoretic mobility shift assays with proteins overexpressed in COS cells and with nuclear extracts from tumor necrosis factor alpha-stimulated HeLa cells demonstrated a strong cooperative binding of C/EBP to its site when NF-KB is bound to its adjacent binding site. Transfection studies lead to a model that suggests a highly complex regulation of interleukin-8 gene expression at multiple levels: independent binding of C/EBP and NF-kB to their respective sites, cooperative binding of C/EBP and NF- $K B$ to DNA, and positive synergistic activation through the C/EBP binding site and inhibition through the NF-kB binding site by combinations of C/EBP and NF-кB. Thus, the ultimate regulation of interleukin-8 gene expression depends on the ratio of cellular C/EBP and NF-kB.
\end{abstract}

Regulation of gene expression at the transcriptional level is mediated by transcription factors binding to cis-acting DNA elements in the promoter regions of the respective genes. Transcription factors can act as activators or inhibitors of gene transcription. In addition, many genes are controlled by simultaneous binding of diverse transcription factors to cis-acting DNA elements in the same promoter. Recently a novel mechanism of gene regulation has emerged; in this mechanism, cross-family interaction, one transcription factor modulates the activity of another by direct physical interaction. Examples are the interaction between the glucocorticoid receptor and the AP-1 proteins Jun and Fos $(15,21,27,38,44)$ and the interaction of Jun with MyoD (8). We have recently shown the functional and physical association of NF-кB family members with Jun/Fos proteins (39) and with C/EBP family members (40). The interaction with C/EBP results in the inhibition of promoters with $\kappa B$ enhancer motifs and in synergistic stimulation of promoters with $\mathrm{C} / \mathrm{EBP}$ binding sites. NF- $\mathrm{KB}$ and $\mathrm{C} / \mathrm{EBP}$ are activated by important inflammatory cytokines such as interleukin-1 (IL-1) and IL-6, respectively $(34,35)$. Therefore, the interaction between NF- $\mathrm{BB}$ and $\mathrm{C} / \mathrm{EBP}$ might be involved in $T$-cell activation and the acute-phase response $(1,19,42)$. In this regard, several promoters that have closely spaced NF- $\mathrm{kB}$ and $\mathrm{C} / \mathrm{EBP}$ binding sites have been cloned. Examples are the acute-phase response gene encoding serum amyloid $\mathrm{Al}$ as well as the angiotensinogen, IL-6, and IL-8 genes $(12,20,26,29)$.

IL-8 is a novel cytokine that is produced by a variety of human somatic cells and several types of human tumor cell lines (references 24 and 45 and references therein). IL- 8 has T-cell, neutrophil, and basophil chemotactic properties (for a review, see reference 28). The production of IL-8 is not

\footnotetext{
${ }^{*}$ Corresponding author.

† Present address: Signal Pharmaceuticals, San Diego, CA 92121.
}

constitutive and can be induced by various agents such as lipopolysaccharides, IL-1, tumor necrosis factor alpha (TNF- $\alpha$ ), and phorbol myristate acetate (PMA) (for a review, see 28). Deletion analyses of the IL-8 promoter showed that the sequences between positions -91 and -71 are necessary and sufficient for the induction of IL-8 gene transcription by IL- 1 , TNF- $\alpha$, and PMA in human fibrosarcoma cells (29). This region of the promoter contains a putative $\mathrm{C} / \mathrm{EBP}$ and a putative NF- $\mathrm{kB}$ binding site.

In this study, we show that several members of the NF-kB family can bind to the proposed $\kappa B$ enhancer motif found in the IL-8 promoter. We further show that binding of NF- $k B$ to its site results in the strong cooperative binding of $C / E B P$ to its adjacent site. Treatment of HeLa cells with TNF- $\alpha$ induces a similar cooperative binding of these factors to DNA. We propose a highly complex regulation of IL-8 gene expression by distinct mechanisms involving binding of C/EBP and NF-кB family members to cis DNA elements as well as physical protein-protein interactions of C/EBP with NF- $\mathrm{kB}$.

\section{MATERIALS AND METHODS}

Plasmid constructs. The C/EBP-TATA-chloramphenicol acetyltransferase (CAT) reporter plasmid has been described elsewhere (40). The IL-8 wt (wild-type) reporter was generated by cloning a single copy of an oligonucleotide encompassing the bp -97 to -69 region of the human IL-8 gene (5'-AGCTTCATCAGTTGCAAATCGTGGAATTTCC TCTG-3') (binding sites for C/EBP and NF- $\kappa B$ are in boldface type) into HindIII-BamHI-cut TATA-CAT. The IL-8 mкB-TATA-CAT and IL-8 mC/EBP-TATA-CAT reporter plasmids contain oligonucleotides with point mutations in the NF- $\mathrm{kB}$ binding site $\left(5^{\prime}\right.$-AGCTTCATCAGTTGCAAAT CGTTTAACTTTCCTCTG-3') (point mutations are underlined) and the C/EBP binding site (5'-AGCTTCATCAGㄷ 
TACGAGTCGTGGAATTTCCTCTG-3') (point mutations are underlined), respectively. Plasmids pCMV4T, pCMV4Tp65, pCMV4T-p50, and pCMV4T-rC/EBP $\beta$ have been described previously (40). The expression vector pCMV4T-hcRel is described elsewhere (5).

Transfection of cells and analysis of CAT activity. All cell lines were cultured in Iscove's Dulbecco modified Eagle medium supplemented with $7.5 \%$ fetal calf serum and antibiotics. Mouse F9 embryonal carcinoma cells were transiently transfected by the calcium phosphate method (17). HeLa cells were transiently transfected with plasmid DNA by the DEAE-dextran method (22). CAT enzymatic activity was assayed as previously described (32) and normalized for protein recovery (11).

Extract preparation. Whole-cell extracts from COS cells transfected with NF- $\mathrm{B}$ expression vectors were prepared by a method used to prepare CAT assay extracts (2) 3 days posttransfection. Nuclear extracts from HeLa cells were prepared as described elsewhere (41) and were a generous gift of Amer A. Beg. Mouse C/EBP $\beta$ protein expressed in bacteria (14) was a generous gift of Steven L. McKnight.

EMSAs. Electrophoretic mobility shift assays (EMSAs) were performed as previously described (41). The binding buffer contained $12 \mathrm{mM} N$-2-hydroxyethylpiperazine- $N^{\prime}-2$ ethanesulfonic acid (HEPES)-NaOH (pH 7.9), $4 \mathrm{mM}$ Tris(pH 7.9), $60 \mathrm{mM} \mathrm{KCl,} 5 \mathrm{mM} \mathrm{MgCl}, 0.6$ mM EDTA, $12 \%$ glycerol, and $5 \mathrm{mM}$ dithiothreitol. The IL-8 wt binding site was created by annealing the two oligonucleotides $5^{\prime}$-AGCT TCATCAGTTGCAAATCGTGGAATTTCCTCTG-3' and 5' $^{\prime}$ TAGCCAGAGGAAATTCCACGATTTGCAACTGATGA-3' (binding sites for C/EBP and NF-kB are in boldface type). The IL- $8 \mathrm{m \kappa B}$ binding site was created by annealing the two oligonucleotides 5 '-AGCTTCATCAGTTGCAAATCGTTA ACTTTCCTCTG-3' and 5'-TAGCCAGAGGAAAGTTAAC GATTTGCAACTGATGA-3' (point mutations are underlined). The IL- $8 \mathrm{mC} / \mathrm{EBP}$ binding site was created by annealing the two oligonucleotides 5'-AGCTTCATCAGCTA CGAGTCGTGGAATTTCCTCTG- ${ }^{\prime}$ and 5'-TAGCCAGA GGAAATTCCACGACTCGTAGCTGATGA-3' (point mutations are underlined). The 65-2 and human immunodeficiency virus type 1 (HIV-1) $\mathbf{\kappa B}$ oligonucleotides have been described elsewhere (25), as have the oligonucleotide with a core C/EBP binding site derived from the c-fos serum response element (40) and the AP-1 oligonucleotide encompassing the collagenase promoter AP-1 binding site (3).

Antibodies. Anti-p65 is antiserum raised against an N-terminal peptide of NF-кB p65 (7). Anti-p50 antiserum was obtained from Alain Israël, anti-c-Rel antiserum was obtained from Nancy Rice, anti-C/EBP $\beta$ antiserum was obtained from Steven McKnight, and anti-p52 antiserum was obtained from Michael Karin. Antisera $(1 \mu \mathrm{l})$ were added to EMSA reaction mixtures for $1 \mathrm{~h}$ at $4^{\circ} \mathrm{C}$ prior to addition of the radiolabeled probe.

\section{RESULTS}

Cooperative binding of NF-KB and C/EBP to the IL-8 promoter. The IL-8 promoter has been previously cloned and sequenced (30). The 5' flanking promoter region contains potential binding sites for AP-1, AP-2, interferon regulatory factor 1 , hepatocyte nuclear factor 1 , glucocorticoid receptor, C/EBP, and NF- $\mathrm{kB}$ (29). Promoter deletion analyses showed that sequences between positions -91 and -71 are necessary and sufficient for the responsiveness to IL-1, TNF- $\alpha$, and PMA in human fibrosarcoma cells (29). This region contains potential binding sites for $\mathrm{C} / \mathrm{EBP}$ and NFкB.

To study whether NF-kB family members can bind to the IL-8 promoter, EMSAs were performed with an oligonucleotide probe (IL-8 wt) encompassing the region between -97 bp and $-69 \mathrm{bp}$ and therefore containing both the potential $\mathrm{C} / \mathrm{EBP}$ and NF-kB binding sites. Several COS cell-expressed NF-kB family members, including NF-kB p65, NF-kB p50, NF-kB p50/p65 heterodimers, and c-Rel, bound specifically to the IL-8 wt probe (Fig. 1A, lanes 7 to 10), while no binding activity was detected with control extracts from mock-transfected COS cells (lane 6). Bacterially expressed C/EBP $\beta$ showed only weak binding by itself to IL-8 wt (lane 1) but caused a supershifted band in the presence of several different NF-kB proteins (lanes 2 to 5 ). We found the strongest supershift with NF-kB p65 (lane 2), while a supershift with NF-kB p50 was detectable only after longer exposure of the gel (lane 3 and data not shown). The supershifted band indicates that the binding of C/EBP is strongly stimulated when NF- $\mathrm{KB}$ is bound to its adjacent site and that the two factors bind to the same oligonucleotide. An approximate fold increase in binding of C/EBP in the presence of NF- $\mathrm{NB}$ can be calculated by comparing the relative intensity of the supershifted complex with that of the complex of C/EBP alone. The increase in NF- $\mathrm{KB}$ p65 binding is represented by the same calculated ratio and is much lower since NF- $\mathrm{BB}$ already binds to the IL-8 site with high affinity.

We were next interested in whether C/EBP and NF-кB are able to occupy their respective adjacent cis-acting DNA elements at the same time. For this study, we used three different oligonucleotide probes, IL-8 wt, IL-8 mkB with point mutations in the $\mathrm{\kappa B}$ enhancer motif, and IL-8 mC/EBP with point mutations in the C/EBP binding site. EMSAs with bacterially expressed $C / E B P \beta$ showed that $C / E B P \beta$ bound to IL-8 wt and IL-8 $\mathrm{m \kappa B}$, although weakly with the amounts used (Fig. 1B, lanes 1 and 4). NF-kB p65 expressed in vivo in COS cells bound to IL-8 wt and IL-8 mC/EBP (lanes 3 and 9). This finding indicates that the point mutations in IL-8 $\mathrm{m} \kappa \mathrm{B}$ and IL-8 mC/EBP disrupt only the targeted binding site and that $\mathrm{C} / \mathrm{EBP} \beta$ as well as NF-KB can bind by themselves to their respective sites. When we added a combination of $\mathrm{C} / \mathrm{EBP} \beta$ and NF-kB, a strong supershifted band was observed with the wild-type probe only (lane 2 ). This result and the absence of supershifted bands with IL-8 $\mathrm{m \kappa B}$ and IL-8 mC/EBP clearly demonstrate a cooperative binding of $\mathrm{C} / \mathrm{EBP}$ to its target sequence when $\mathrm{NF}-\mathrm{kB}$ is bound to its high-affinity site.

Analysis of NF-אB family member binding to the IL-8 promoter. To ultimately define the functional properties of the NF- $\mathrm{BB}$ binding site in the IL-8 promoter, we compared this site with sequences listed in a recent publication (25). The IL-8 promoter NF-kB binding site matches, over the core $\kappa B$ consensus element, a DNA sequence termed 65-9. This sequence is listed as a selective NF- $\mathrm{KB}$ binding site that

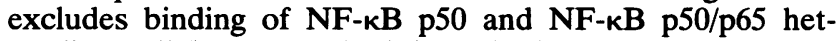
erodimers (25). Our results (Fig. 1A) with proteins expressed in COS cells clearly demonstrated binding of NF-kB p50/p65 heterodimers and NF-kB p50 to this site. To further analyze this, we compared binding of NF-kB p65 homodimers, NF-kB p50 homodimers, and NF-kB p50/p65 heterodimers to the HIV-1 $\mathrm{\kappa B}$ enhancer, a site known to bind all three forms, with that of $65-2$, another selective NF-kB binding site described as not binding to NF- $\mathrm{kB}$ p50 homodimers or to $\mathrm{NF}-\mathrm{kB}$ p50/p65 heterodimers (25), and with that of the IL-8 wt site. All three COS cell-expressed NF- $\mathrm{KB}$ forms were able to bind to the three different probes (Fig. 2A). It 
A

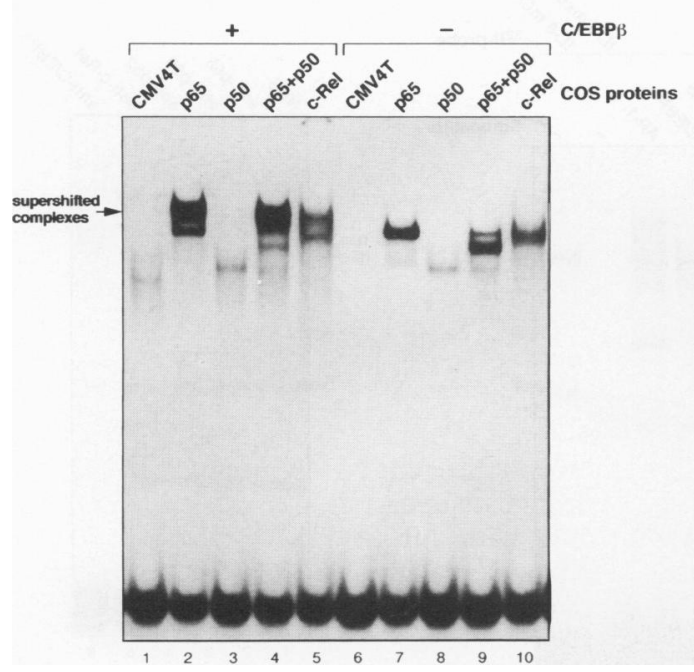

B

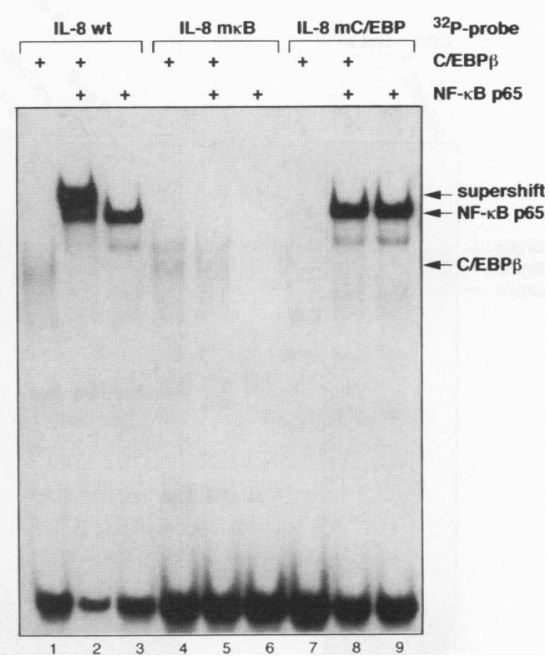

FIG. 1. Cooperative binding of NF- $\mathrm{KB}$ and C/EBP to the IL-8 promoter. (A) Extracts from COS cells transiently transfected with a control vector (CMV4T) or expression vectors for NF-kB family members were incubated in the presence (lanes 1 to 5) or absence (lanes 6 to 10) of bacterially expressed C/EBPB for $15 \mathrm{~min}$ at room temperature (RT) in EMSA buffer with $0.1 \mu \mathrm{g}$ of poly(dI-dC) and $5 \mu \mathrm{g}$ of bovine serum albumin (BSA). After addition of ${ }^{32} \mathrm{P}$-labeled probe (IL-8 wt) and incubation at RT for $30 \mathrm{~min}$, DNA-protein complexes were analyzed by EMSA with $0.25 \times$ Tris-borate-EDTA native gels. (B) Bacterially expressed C/EBP $\beta$ and COS cell-expressed NF- $\mathrm{kB}$ p65 were incubated as indicated for $15 \mathrm{~min}$ at RT in EMSA buffer with 0.1 of $\mu \mathrm{g}$ poly(dI-dC) and $5 \mu \mathrm{g}$ of BSA. After addition of ${ }^{32} \mathrm{P}-$ labeled probe (IL-8 wt, lanes 1 to 3 ; IL-8 mkB, lanes 4 to 6; IL-8 mC/EBP, lanes 7 to 9) and incubation at RT for $30 \mathrm{~min}$, DNA-protein complexes were analyzed by EMSA with $0.25 \times$ Tris-borate-EDTA native gels. The arrows indicate the positions of the respective protein-DNA complexes. All COS cell-expressed NF-kB family members were produced at similar levels, as assessed by Western blot analysis (data not shown).

appeared that $65-2$ and IL-8 wt preferred the heterodimer over the respective homodimers (Fig. 2A, lanes 5 and 8). We also analyzed binding of nuclear extracts from TNF- $\alpha-$ treated HeLa cells to these three probes (Fig. 2B). We used IL-8 $\mathrm{mC} / \mathrm{EBP}$ as the binding site instead of IL-8 wt to exclude any interference on NF- $\mathrm{BB}$ binding coming from the C/EBP binding site (see below). EMSAs demonstrated the presence of two specific DNA-protein complexes, termed II and III, with all three probes. Complex II was characterized to contain heterodimers of NF- $\mathrm{kB}$ p 65 with other members of the NF- $\kappa B$ family and possible NF- $\kappa$ B p 65 homodimers, while complex III contains NF-kB p50/p65 heterodimers and a potential p50/Rel heterodimer (6) (Fig. 3C and data not shown). These data confirm our results with the COS proteins indicating that all three probes are capable of binding NF- $k B$ p50/p65 heterodimers, although the IL-8 probe preferentially forms complex II with $\mathrm{HeLa}$ nuclear extracts. To further analyze this issue, we tested binding of bacterially expressed NF-kB p50 (a gift from C. Rosen) to these sites. Consistent with the data of Kunsch et al. (25), bacterially expressed NF- $\mathrm{kB}$ p50 did not bind to 65-2 and IL-8 wt (data not shown). This finding strongly suggests that a modification of NF-kB and/or the source and kind of purification of $\mathrm{NF}-\mathrm{kB}$ have a strong influence on its binding characteristics. In conclusion, the three binding sites analyzed here, including the IL-8 element, do not exclude binding of NF- $\mathrm{kB}$ p50 and NF-kB p50/p65.

Cooperative binding of NF- $\kappa B$ and C/EBP after TNF- $\alpha$ stimulation. Our in vitro binding studies clearly demonstrated cooperative binding of C/EBP and NF-KB to an IL-8 promoter element that has been reported to mediate induction by TNF- $\alpha$ (29). To analyze which proteins in cells bind to this IL-8 promoter sequence, we performed EMSAs with nuclear extracts from unstimulated and TNF- $\alpha$-treated HeLa cells (Fig. 3A). We selected HeLa cells for these
A

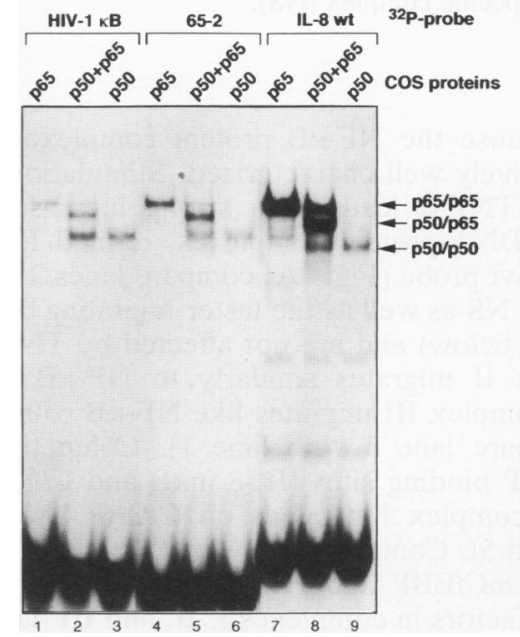

B

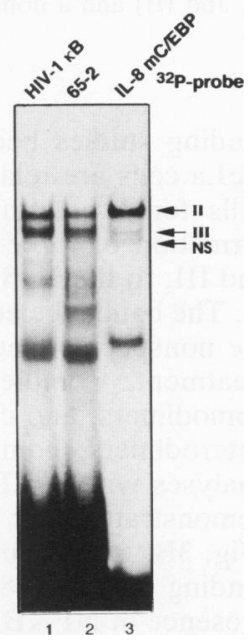

FIG. 2. Analysis of binding of NF-kB family members. (A) Extracts from COS cells transiently transfected with pCMV4T-p65, pCMV4T-p50, or a combination of the two were incubated at RT in EMSA buffer with $0.1 \mu \mathrm{g}$ of poly(dI-dC) and $5 \mu \mathrm{g}$ of BSA. After addition of ${ }^{32} \mathrm{P}$-labeled probe (HIV-1 $\mathrm{kB}$, lanes 1 to 3; 65-2, lanes 4 to 6; IL-8 wt, lanes 7 to 9) and incubation at RT for $30 \mathrm{~min}$, DNA-protein complexes were analyzed by EMSA with $0.25 \times$ Tris-borate-EDTA native gels. The arrows indicate the positions of the respective NF-kB-DNA complexes. (B) Nuclear extracts from HeLa cells prepared $1 \mathrm{~h}$ after treatment with TNF- $\alpha(10 \mathrm{ng} / \mathrm{ml}$; Genentech) were incubated at RT in EMSA buffer with $0.5 \mu \mathrm{g}$ of poly(dI-dC). After addition of ${ }^{32} \mathrm{P}$-labeled probe (HIV-1 $\mathrm{kB}$, lane 1; 65-2, lane 2; IL-8 $\mathrm{mC} / \mathrm{EBP}$, lane 3) and incubation at RT for $30 \mathrm{~min}$, DNA-protein complexes were analyzed by EMSA with $0.25 \times$ Tris-borate-EDTA native gels. The arrows indicate the positions of two specific DNAprotein complexes (II and III) and a nonspecific complex (NS). 

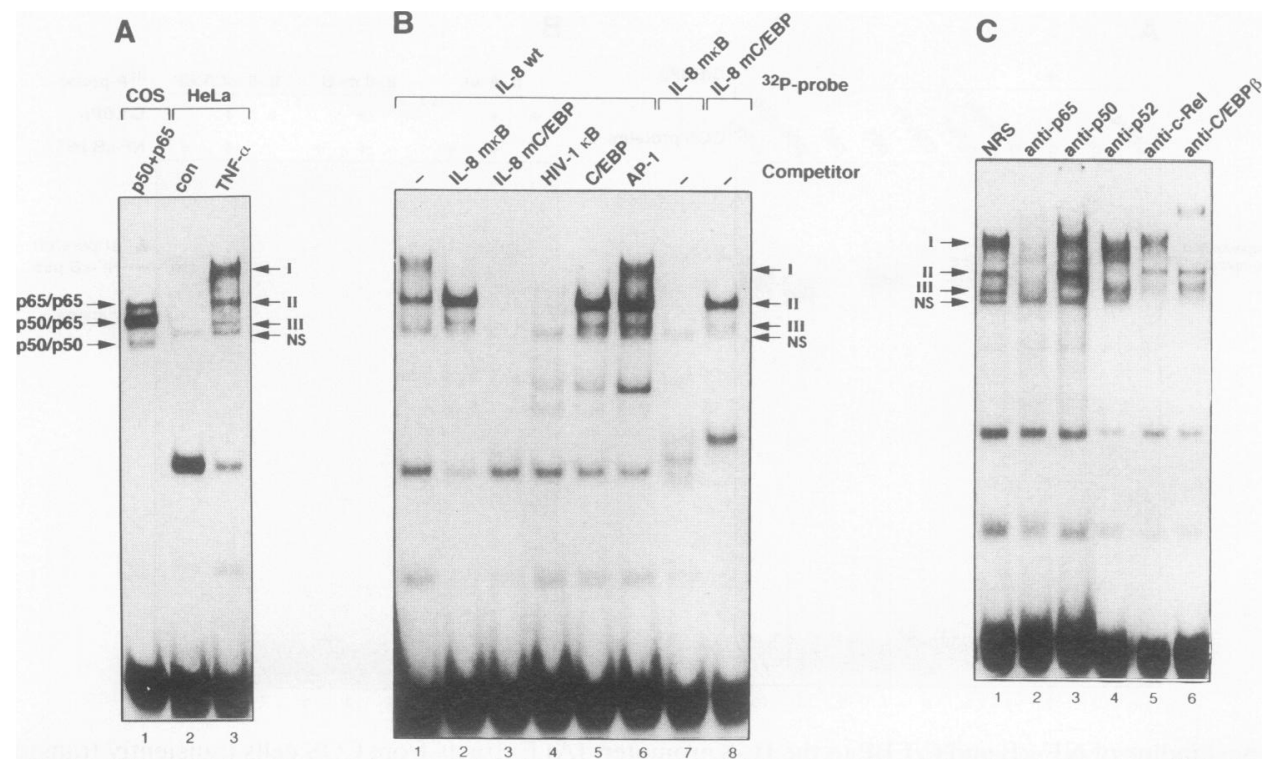

FIG. 3. Cooperative binding of NF-kB and C/EBP after TNF- $\alpha$ stimulation. (A) Nuclear extracts from HeLa cells treated for $1 \mathrm{~h}$ with TNF- $\alpha(10 \mathrm{ng} / \mathrm{ml}$; Genentech) (lane 3) or left untreated (con, lane 2) were incubated at RT in EMSA buffer with $0.5 \mu \mathrm{g}$ of poly(dI-dC). For comparison, lane 1 shows binding of NF-kB p50 and NF- $\mathrm{kB}$ p 65 expressed in COS cells. After addition of ${ }^{32} \mathrm{P}$-labeled probe (IL-8 wt) and incubation at RT for $30 \mathrm{~min}$, DNA-protein complexes were analyzed by EMSA with $0.25 \times$ Tris-borate-EDTA native gels. (B) Nuclear extracts from HeLa cells prepared for $1 \mathrm{~h}$ after treatment with TNF- $\alpha(10 \mathrm{ng} / \mathrm{ml}$; Genentech) were incubated at RT in EMSA buffer with 0.5 $\mu \mathrm{g}$ of poly $\left(\mathrm{dI}-\mathrm{dC}\right.$ ) and a 100 -fold molar excess of each of the indicated competitor oligonucleotides. After addition of ${ }^{32} \mathrm{P}-$ labeled probe (IL-8 wt, lanes 1 to 6; IL-8 mкB, lane 7; IL-8 mC/EBP, lane 8) and incubation at RT for $30 \mathrm{~min}$, DNA-protein complexes were analyzed by EMSA with $0.25 \times$ Tris-borate-EDTA native gels. (C) Nuclear extracts from HeLa cells prepared $1 \mathrm{~h}$ after treatment with TNF- $\alpha$ (10 $\mathrm{ng} / \mathrm{ml}$; Genentech) were incubated for $1 \mathrm{~h}$ at $4^{\circ} \mathrm{C}$ in EMSA buffer with $0.5 \mu \mathrm{g}$ of poly(dI-dC) and $1 \mu \mathrm{l}$ of each of the indicated antibodies or normal rabbit serum (NRS, lane 1). After addition of ${ }^{32} \mathrm{P}$-labeled probe (IL-8 wt) and incubation at RT for 30 min, DNA-protein complexes were analyzed by EMSA with $0.25 \times$ Tris-borate-EDTA native gels. The arrows indicate the positions of three specific DNA-protein complexes (I, II, and III) and a nonspecific complex (NS).

binding studies because the NF- $\mathrm{BB}$ protein complexes in HeLa cells are relatively well characterized, Stimulation of cells for $1 \mathrm{~h}$ with TNF- $\alpha$ leads to a strong increase in formation of three DNA-protein complexes, termed I, II, and III, to the IL- 8 wt probe (Fig. 3A; compare lanes 2 and 3 ). The band labeled NS as well as the faster-migrating band are nonspecific (see below) and are not affected by TNF- $\alpha$ treatment. Complex II migrates similarly to NF- $\mathrm{BB}$ p65 homodimers, and complex III migrates like NF-kB p50/p65 heterodimers (compare lane 3 with lane 1). Competition analyses with C/EBP binding sites (IL-8 mkB and C/EBP) demonstrated that complex I depends on C/EBP binding (Fig. 3B, lanes 2 and 5). Competition analyses with NF-kB binding sites (IL-8 $\mathrm{mC} / \mathrm{EBP}$ and HIV-1 $\mathrm{kB}$ ) showed the presence of NF- $\mathrm{KB}$ factors in complexes I, II, and III (lanes 3 and 4). An unrelated oligonucleotide (AP-1) did not compete for binding. We further confirmed these data by using IL-8 $\mathrm{m \kappa B}$ and IL-8 $\mathrm{mC} / \mathrm{EBP}$ as radiolabeled probes (lanes 7 and 8). From these experiments, we conclude that complex I contains both NF- $\mathrm{kB}$ and C/EBP factors and that complexes II and III contain NF-kB protein. The band labeled NS is not affected by the competitors.

Antibody studies confirmed our EMSA competition data. Antibodies against NF-kB p65 strongly diminished complexes I, II, and III (Fig. 3C, lane 2). Anti-p50 slightly diminished complex I, did not affect complex II, and blocked formation of complex III. Anti-p52 blocked formation of complex II only. The slight difference in complex I migration in the presence of anti-p52 antibodies is likely caused by different concentrations of proteins and buffer due to the antiserum. Anti-c-Rel diminished all three EMSA protein complexes weakly. Anti-C/EBP $\beta$ abolished complex I only and resulted in a supershifted band (Fig. 3C, lane 6). From these data, we conclude that NF-kB p65 and to a lesser extent c-Rel participate in complexes I, II, and III, while $\mathrm{NF}-\kappa \mathrm{B}$ p50 participates in complex III and in smaller amounts in complex I. Complex II contains predominantly NF- $\kappa$ B p 65 and NF- $\mathrm{B}$ p52, and complex III seems to be an $\mathrm{NF}-\mathrm{kB}$ p50/p65 and p50/Rel heterodimer. In conclusion, most of the supershifted complex I contains NF- $\mathrm{kB}$ p65 and $\mathrm{C} / \mathrm{EBP}$. This finding is consistent with the data shown in Fig. 1A, which demonstrate strongest cooperative binding of C/EBP with NF-kB p65 but only weak cooperativity with $\mathrm{NF}-\kappa \mathrm{B}$ p50.

Complex regulatory mechanisms play a role in IL-8 gene activation. We have previously shown that NF-kB and C/EBP functionally and physically interact. This crosscoupling results in inhibition of promoters with NF-kB binding sites and in synergistic stimulation of promoters with C/EBP binding sites (40). The IL-8 promoter is an example of a promoter in which the two binding sites are located close together. Our in vitro experiments showed a cooperative binding of NF- $\kappa \mathrm{B}$ and $\mathrm{C} / \mathrm{EBP}$ to their adjacent binding sites. Therefore, we were interested how NF-kB and C/EBP regulate the IL-8 promoter in vivo. We selected F9 embryo carcinoma cells for these studies because of their very low levels of endogenous nuclear NF- $\mathrm{BB}$ activity. Since the IL-1, TNF- $\alpha$, and PMA responsiveness of the IL-8 promoter in fibrosarcoma cells was narrowed down to sequences between positions -91 and -71 (29), we used minimal pro- 
A

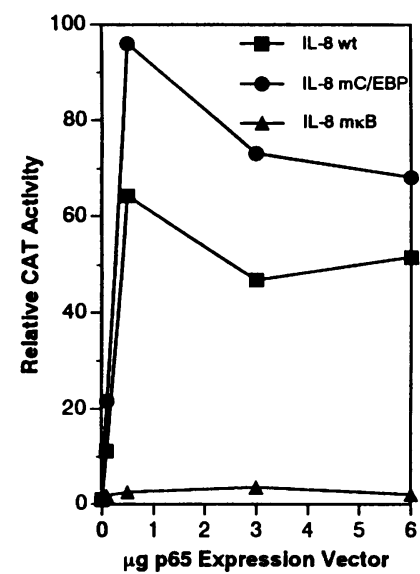

B

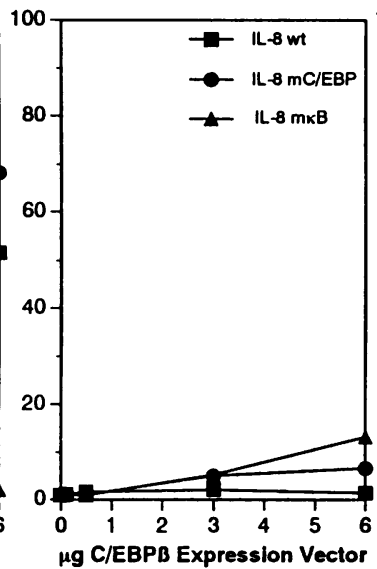

C

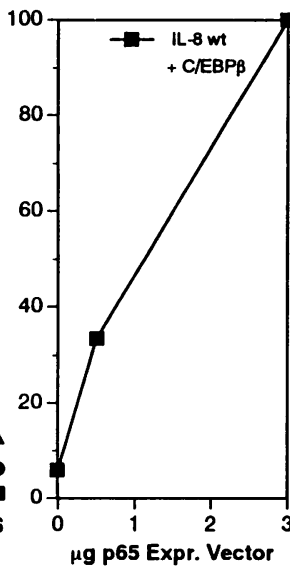

D

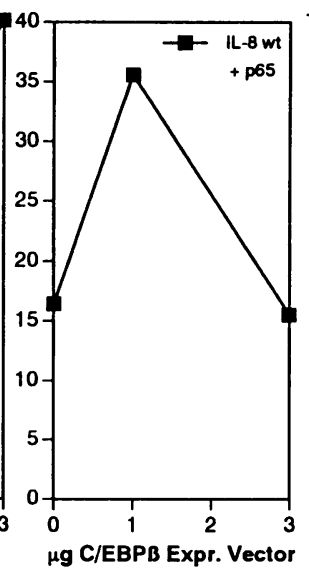

E

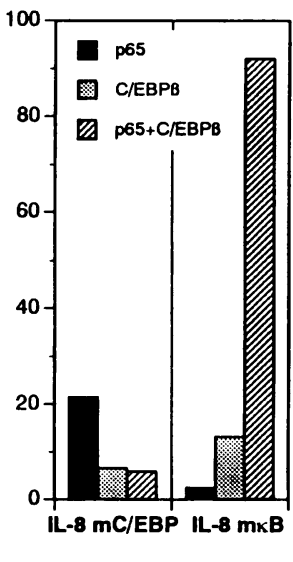

FIG. 4. Cross-coupling of NF- $\mathrm{kB}$ and C/EBP. Mouse F9 embryonal carcinoma cells were transiently transfected with $8 \mu \mathrm{g}$ of CAT reporter plasmid IL-8 wt-TATA-CAT, IL-8 mkB-TATA-CAT, or IL-8 mC/EBP-TATA-CAT and increasing amounts (0.1 to $6 \mu \mathrm{g})$ of pCMV4T-p65 (A) or pCMV4T-rC/EBPB (B) expression vector. (C) Mouse F9 embryonal carcinoma cells were transiently transfected with $8 \mu \mathrm{g}$ of CAT reporter plasmid IL-8 wt-TATA-CAT, $6 \mu \mathrm{g}$ of pCMV4T-rC/EBP $\beta$, and increasing amounts of pCMV4T-p65. (D) Mouse F9 embryonal carcinoma cells were transiently transfected with $8 \mu \mathrm{g}$ of CAT reporter plasmid IL-8 wt-TATA-CAT, $0.1 \mu \mathrm{g}$ of pCMV4T-p65, and increasing amounts of pCMV4T-rC/EBPß. (E) Mouse F9 embryonal carcinoma cells were transiently transfected with $8 \mu \mathrm{g}$ of CAT reporter plasmid IL-8 mкB-TATA-CAT or IL-8 mC/EBP-TATA-CAT and $0.1 \mu \mathrm{g}$ of pCMV4T-p65, $6 \mu \mathrm{g}$ of pCMV4T-rC/EBP $\beta$, or a combination of the two. The total amount of transfected DNA was held constant by the addition of the parental pCMV4T vector. Six hours after transfection, CAT activity was determined. CAT activity is presented as fold induction relative to activity obtained with transfected pCMV4T alone. Values shown represent the normalized mean inductive responses from at least three independent experiments. The standard errors were consistently less than $20 \%$ of the means.

moter constructs for these studies. These constructs contain the same oligonucleotides used for the EMSAs encompassing only the C/EBP and NF- $\mathrm{BB}$ binding sites positioned in front of a TATA box linked to the CAT reporter gene. NF- $\mathrm{KB}$ p65 is a very efficient activator of IL-8 wt TATACAT and IL-8 mC/EBP-TATA-CAT reporter genes, while the point mutations in the NF- $\mathrm{KB}$ binding site (IL-8 mkBTATA-CAT) abolished inducibility by NF-kB p65 (Fig. 4A). Consistent with our EMSAs, C/EBP activates the IL-8 promoter very weakly at higher concentrations only (Fig. 4B). Transfection of IL-8 wt-TATA-CAT with a constant amount of $\mathrm{C} / \mathrm{EBP}$ and increasing amounts of NF-kB p65 resulted in a dose-dependent increase of CAT activity (Fig. 4C). When we cotransfected the IL-8 wt-TATA-CAT reporter with NF-kB p65 and increasing amounts of C/EBP, we observed an increase or an inhibition of CAT activity, depending on the ratio of NF-kB p65 and C/EBP (Fig. 4D). As stated above, NF- $\kappa B$ and C/EBP synergistically activate promoters with $\mathrm{C} / \mathrm{EBP}$ binding sites but inhibit promoters with $\kappa \mathrm{B}$ binding sites. Since the IL- 8 promoter has binding sites for both factors, we suspected a highly complex regulation depending on the ratio of both factors. To test this hypothesis, we cotransfected NF-kB p65 and C/EBP together with IL-8 mC/EBP-TATA-CAT, a $\kappa B$-dependent promoter. As expected, C/EBP inhibited the induction by NF-kB p65 (Fig. 4E). The inhibition by C/EBP was dose dependent and never resulted in an increase of CAT activity (data not shown). Cotransfection of NF-kB p65 and C/EBP with a C/EBP-dependent promoter, IL-8 mкB-TATA-CAT, resulted in strong synergistic activation (Fig. 4E). Under comparable conditions, the induction of the IL-8 wt promoter by NF-кB p65 was inhibited by C/EBP (compare with Fig. $4 \mathrm{D}, 3 \mu \mathrm{g}$ of $\mathrm{C} / \mathrm{EBP} \beta$ expression vector). Thus, the IL-8 promoter combines the properties of a $\mathrm{kB}$ - and a C/EBP- dependent promoter. Western blot (immunoblot) analyses showed that NF- $\mathrm{kB}$ p 65 had no effect on the expression of cotransfected C/EBP expression vectors and, vice versa, that $\mathrm{C} / \mathrm{EBP}$ did not change the expression of cotransfected NF- $\mathrm{kB}$ p65 expression vectors (40). These results suggest that distinct nuclear factors, NF- $\mathrm{BB}$ and $\mathrm{C} / \mathrm{EBP}$, bind to independent cis DNA elements in the IL-8 promoter, although their binding under nonstimulated conditions is likely to be weak. However, treatment of cells with cytokines such as TNF- $\alpha$ results in cooperative binding of $\mathrm{C} / \mathrm{EBP}$ and $\mathrm{NF}-\kappa \mathrm{B}$ to their adjacent binding sites. IL-8 gene expression is further regulated by protein-protein interactions between $\mathrm{C} / \mathrm{EBP}$ and NF-kB . This results in synergistic activation through the C/EBP binding site and in antagonistic inhibition through the NF-kB binding site (see Discussion and Fig. 5 for a model of IL-8 gene regulation).

\section{DISCUSSION}

The IL-8 promoter is transcriptionally activated by various agents such as IL-1, TNF- $\alpha$, and the hepatitis B virus $X$ protein. Further, by using several deletion mutants, it has been shown that a cis DNA element between positions -91 and -71 is necessary for the induction of the IL-8 gene by these agents in fibrosarcoma cells. This DNA region was described as a putative C/EBP-like and a putative NF- $\mathrm{kB}-$ like binding site. It has been reported that both sites cooperate in the induction of the IL-8 gene, but it has not been shown that this is actually caused by a cooperative binding of $\mathrm{C} / \mathrm{EBP}$ and NF- $\kappa \mathrm{B}$ to this region (29). Since NF- $\kappa$ B DNA binding activity is increased by IL- 1 and TNF- $\alpha$, we wanted to analyze whether NF- $\mathrm{BB}$ is able to target the IL-8 promoter $\kappa \mathrm{B}$-like binding site and whether NF- $\mathrm{KB}$ cooperatively binds with $\mathrm{C} / \mathrm{EBP}$ to this site. 
Our experiments clearly demonstrate the cooperative binding of $\mathrm{NF}-\mathrm{kB}$ and $\mathrm{C} / \mathrm{EBP}$ to their adjacent binding sites. NF- $\kappa \mathrm{B}$ and $\mathrm{C} / \mathrm{EBP}$ are two important transcription factor families that are involved in immune and inflammatory functions as well as cell growth and differentiation. NF- $\mathrm{kB}$ is typically composed of a $50-\mathrm{kDa}(10,16,23)$ and a $65-\mathrm{kDa}(33$, 36) subunit that share with other members of this family, such as c-Rel $(13,18)$ and NF-kB p52 $(9,31,37)$, the highly homologous $\mathrm{N}$ terminus, the so-called Rel homology domain. NF- $\mathrm{B}$ family members bind as a dimer to a relatively well-conserved sequence that is found in a variety of genes (4). While NF-kB p65, p50, and c-Rel bound efficiently to the IL-8 $\kappa \mathrm{B}$ site, C/EBP $\beta$, a member of the bZIP family of transcription factors (43), bound only weakly to the C/EBP binding site in the IL-8 promoter (Fig. 1). The formation of a slower-migrating DNA-protein complex (supershift) indicates that the two factors bind to the same oligonucleotide. Competition analyses and selective mutation of either binding site demonstrated that NF- $\mathrm{BB}$ and $\mathrm{C} / \mathrm{EBP}$ bind simultaneously to their adjacent binding sites (Fig. 1). The strongest supershift was observed with NF-kB p65, and the weakest was observed with NF-kB p50. This is also reflected by our EMSA studies with extracts from TNF- $\alpha$-stimulated HeLa cells (Fig. 3). While anti-p50 antibodies had only a weak effect on the supershifted band (complex I), anti-p65 antibodies totally abolished this complex, although this does not rule out the presence of NF- $\mathrm{kB}$ p50/p65 heterodimers in complex I (see below). Interestingly, it appears that NF-kB p52 does not participate in the supershifted complex. The remaining complex II consists predominantly of NF-kB p65/p52 heterodimers. The fact that complex II with a major histocompatibility complex $\kappa \mathrm{B}$ site has been shown to contain, in addition to p65/p5Z heterodimers, NF- $\mathrm{BB}$ p65/Rel heterodimers and possibly NF-kB p65 homodimers (6) suggests that an NF-kB dimer containing p52 may not interact with C/EBP. C-Rel is present in all three complexes at the IL-8 promoter in small amounts. Anti-C/EBP $\beta$ antibodies completely shifted the supershifted band but did not affect the other complexes, indicating the presence of C/EBP family members in complex I. We cannot completely rule out that other members of the NF-kB family are also present together with C/EBP in this supershifted complex but are not efficiently recognized by the respective antisera.

We were unable to detect any binding of C/EBP alone to the IL-8 wt oligonucleotide with extracts from TNF- $\alpha$ stimulated HeLa cells, and experiments with bacterially expressed $\mathrm{C} / \mathrm{EBP} \beta$ showed binding of $\mathrm{C} / \mathrm{EBP}$ that was much weaker than NF-KB binding. This finding suggests that all DNA-bound C/EBP is in the supershifted complex I predominantly together with NF- $\mathrm{kB}$ p65. The cooperative binding of $\mathrm{C} / \mathrm{EBP}$ and NF-kB is most likely based on a direct proteinprotein interaction. C/EBP physically interacts through its bZIP region with the Rel homology domain of NF- $k B$ family members such as NF-kB p65 and p50 (40). This interaction results in synergistic activation of promoters with $\mathrm{C} / \mathrm{EBP}$ binding sites and in inhibition of promoters with NF-kB binding sites (40). We cannot exclude that the binding of NF- $K B$ to DNA also results in a conformational change (DNA bending) of the C/EBP binding site increasing the affinity for C/EBP.

Our in vitro binding studies are complemented by in vivo functional studies. We selected F9 mouse embryo carcinoma cells for these studies since these cells do not express endogenous NF- $\mathrm{kB}$. As expected from our in vitro data, increasing amounts of NF- $\mathrm{kB}$ p65 expression vector lead to strong activation of IL-8 wt-TATA-CAT and IL-8 mC/EBP-

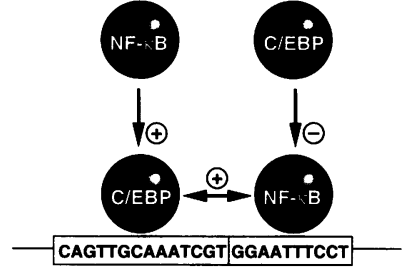

FIG. 5. Model for binding of C/EBP and NF- $\mathrm{KB}$ to their adjacent binding sites in the IL-8 promoter. $\oplus$, cooperativity of C/EBP and NF-кB; $\downarrow \oplus$, positive synergistic activation of C/EBP by NF-кB; $\downarrow \Theta$, inhibition of NF-kB by C/EBP.

TATA-CAT reporters. On the other hand, we were unable to detect any specific activation of IL- 8 promoter constructs by the $\mathrm{C} / \mathrm{EBP}$ expression vector. This finding confirms our EMSA data demonstrating that $\mathrm{C} / \mathrm{EBP}$ in the absence of $\mathrm{NF}-\kappa \mathrm{B}$ binds only very weakly.

Interestingly, cotransfection of NF-kB p65 and C/EBP demonstrated that the IL-8 promoter behaves like a C/EBPdependent and an NF-кB-dependent promoter. The ratio of NF-kB p65 and C/EBP determines whether the IL-8 promoter is activated or inhibited (Fig. 4D and E). Further, when the C/EBP binding site was mutated (IL-8 mC/EBP), C/EBP inhibited the induction by NF-kB p65 (Fig. 4E). This is similar to results that we obtained with other NF-kBdependent promoters (40). In contrast, when the NF-kB binding site was mutated, the cotransfection of NF- $\mathrm{KB}$ and C/EBP resulted in strong synergistic activation of IL-8 mкB-TATA-CAT (Fig. 4E). This is similar to results that we obtained with C/EBP-dependent promoters (40). These data suggest that the mechanism of synergistic activation of IL-8 mкB-TATA-CAT is mainly dependent on increased transcriptional activity rather than increased DNA binding (Fig. $1 B$, lane 5) (40).

It has been shown previously that both the C/EBP and NF- $\mathrm{kB}$ binding sites are necessary for TNF- $\alpha$ induction of the IL-8 promoter (29). These transfection studies were done in cells with a constitutive amount of endogenous C/EBP (29). TNF- $\alpha$ increases the amount of active NF- $\kappa B$ in the nucleus, which, according to our model, will cooperatively stimulate binding of C/EBP to the IL-8 promoter. A mutation in the C/EBP binding site will still allow binding of NF- $\kappa B$ to its site, but the physical interaction of C/EBP with NF-kB may result in an inhibition of $\mathbf{k B}$-dependent gene transcription (40). In contrast, our transfection studies in F9 cells were done with an excess of NF-kB p65 and very low amounts of endogenous C/EBP. Under these conditions, NF- $k \mathrm{~B}$ p 65 by itself will be able to activate the IL-8 gene through the $\kappa B$ binding site.

We therefore propose that the IL-8 promoter has a highly complex regulation by three potential mechanisms (Fig. 5). The first level of regulation is the binding of C/EBP or $\mathrm{NF}-\mathrm{kB}$ to their respective binding sites. This results at least for NF- $\mathrm{KB}$ in positive transcriptional regulation (Fig. 4A). It should be stated that in unstimulated cells, neither C/EBP nor NF-kB may be able to bind to the IL-8 promoter. The second level of regulation is the cooperative binding of $\mathrm{C} / \mathrm{EBP}$ and NF-kB to their adjacent binding sites. From our in vitro binding studies, we believe that a C/EBP-NF- $\mathrm{BB}$ DNA complex is highly preferred over a C/EBP-DNA or NF-kB-DNA complex (Fig. 1 and 3). The third level of gene regulation is a new mechanism delineated from our previous publication (40). If NF- $\mathrm{KB}$ is in excess, it may interact with 
C/EBP bound to the C/EBP site, which then results in positive synergistic activation through the $\mathrm{C} / \mathrm{EBP}$ binding site (Fig. 4E). On the other hand, an excess of C/EBP will inhibit NF- $\mathrm{KB}$ bound to the $\kappa \mathrm{B}$ binding site (Fig. 4E). This is also shown by cotransfecting IL-8 wt-TATA-CAT with a constant amount of NF-kB p65 and two different amounts of C/EBP (Fig. 4D). If cooperative binding of $C / E B P$ and NF- $\mathrm{KB}$ to the IL-8 site occurs, this will likely exclude both of the other two mechanisms.

The conditions in the cell that favor the active versus the inactive state of transcription are likely to be complex. IL-1, TNF- $\alpha$, PMA, and hepatitis $B$ virus $X$ protein are all activators of IL-8 gene transcription. These agents are also known to activate NF-kB. Further, multimerized IL-8 NF- $\kappa$ B binding sites, in contrast to multimerized C/EBP binding sites, are sufficient to mediate activation by these agents (29). This finding suggests that NF-kB plays the more important role in IL-8 gene regulation but that its activity is modulated by C/EBP. The relative concentrations of each transcription factor and the relative affinities to each other and to DNA will ultimately determine whether the IL-8 promoter is activated or inhibited. Since adjacent C/EBP and NF- $\mathrm{KB}$ binding sites are found in a variety of promoters, the demonstrated functional and physical interaction between these two transcription factor families might be a general mechanism of cytokine-induced gene regulation.

\section{ACKNOWLEDGMENTS}

We thank Amer Beg, Alain Israël, Michael Karin, Steven McKnight, Nancy Rice, and Craig Rosen for valuable reagents.

This research was supported by a grant (to A.S.B.) from the National Institutes of Health (CA 52515), by an Arthritis Foundation Research Award, by an RJR-Nabisco Scholar Award in Immunology, and by an American Cancer Society Junior Faculty Research Award (JFRA-309).

\section{ADDENDUM IN PROOF}

Two recent articles (W. Kaszubska, R. Hooft van Huijsduijnen, P. Ghersa, A.-M. DeRaemy-Schenk, B. P. C. Chen, T. Hai, J. F. DeLamarter, and J. Whelan, Mol. Cell. Biol. 13:7180-7190, 1993; and W. Du, D. Thanos, and T. Maniatis, Cell 74:887-898, 1993) demonstrate functional and physical associations between the ATF bZIP proteins and NF-kB.

\section{REFERENCES}

1. Akira, S., T. Hirano, T. Taga, and T. Kishimoto. 1990. Biology of multifunctional cytokines: IL-6 and related molecules (IL-1 and TNF). FASEB J. 4:2860-2867.

2. Angel, P., I. Baumann, B. Stein, H. Delius, H. J. Rahmsdorf, and P. Herrlich. 1987. 12-O-tetradecanoyl-phorbol-13-acetate induction of the human collagenase gene is mediated by an inducible enhancer element located in the 5'-flanking region. Mol. Cell. Biol. 7:2256-2266.

3. Angel, P., M. Imagawa, R. Chiu, B. Stein, R. J. Imbra, H. J. Rahmsdorf, C. Jonat, P. Herrlich, and M. Karin. 1987. Phorbol ester-inducible genes contain a common cis element recognized by a TPA-modulated trans-acting factor. Cell 49:729-739.

4. Baeuerle, P. A. 1991. The inducible transcription activator NF-kB: regulation by distinct protein subunits. Biochim. Biophys. Acta 1072:63-80.

5. Ballard, D. W., W. H. Walker, S. Doerre, P. Sista, J. A. Molitor, E. P. Dixon, N. J. Pefier, M. Hannink, and W. C. Greene. 1990 The v-rel oncogene encodes a $\mathrm{kB}$ enhancer binding protein that inhibits NF-kB function. Cell 63:803-814.

6. Beg, A. A., and A. S. Baldwin, Jr. Activation of multiple complexes consisting of four distinct NF-kB/Rel family mem- bers by tumor necrosis factor. Submitted for publication.

7. Beg, A. A., T. S. Finco, P. V. Nantermet, and A. S. Baldwin, Jr. 1993. Tumor necrosis factor and interleukin-1 lead to phosphorylation and loss of $\mathrm{I} \kappa \mathrm{B} \alpha$ : a mechanism for NF- $\mathrm{kB}$ activation. Mol. Cell. Biol. 13:3301-3310.

8. Bengal, E., L. Ransone, R. Scharfmann, V. J. Dwarki, S. J. Tapscott, H. Weintraub, and I. M. Verma. 1992. Functional antagonism between c-Jun and MyoD proteins: a direct physical association. Cell 68:507-519.

9. Bours, V., P. R. Burd, K. Brown, J. Villalobos, S. Park, R.-P. Ryseck, R. Bravo, K. Kelly, and U. Siebenlist. 1992. A novel mitogen-inducible gene product related to $\mathrm{p} 50 / \mathrm{p} 105-\mathrm{NF}-\mathrm{kB}$ participates in transactivation through a $\mathbf{\kappa B}$ site. Mol. Cell. Biol. 12:685-695.

10. Bours, V., J. Villalobos, P. R. Burd, K. Kelly, and U. Siebenlist. 1990. Cloning of a mitogen-inducible gene encoding a $\mathrm{kB}$ DNA-binding protein with homology to the rel oncogene and to cell-cycle motifs. Nature (London) 348:76-80.

11. Bradford, M. M. 1976. A rapid and sensitive method for the quantitation of microgram quantities of protein utilizing the principle of protein-dye binding. Ann. Biochem. 72:248-254.

12. Brasier, A. R., D. Ron, J. E. Tate, and J. F. Habener. 1990. A family of constitutive C/EBP-like DNA binding proteins attenuate the IL-1 $\alpha$ induced NF- $\mathrm{kB}$ mediated trans-activation of the angiotensinogen gene acute-phase response element. EMBO J. 9:3933-3944.

13. Brownell, E., S. J. O'Brien, W. G. Nash, and N. Rice. 1985. Genetic characterization of human c-rel sequences. Mol. Cell. Biol. 5:2826-2831.

14. Cao, Z., R. M. Umek, and S. L. McKnight. 1991. Regulated expression of three C/EBP isoforms during adipose conversion of 3T3-L1 cells. Genes Dev. 5:1538-1552.

15. Diamond, M. I., J. N. Miner, S. K. Yoshinaga, and K. R. Yamamoto. 1990. Transcription factor interactions: selectors of positive or negative regulation from a single DNA element. Science 249:1266-1272.

16. Ghosh, S., A. M. Gifford, L. R. Riviere, P. Tempst, G. P. Nolan, and D. Baltimore. 1990. Cloning of the p50 DNA binding subunit of NF-kB: homology to rel and dorsal. Cell 62:1019-1029.

17. Graham, F. L., and A. J. van der Eb. 1973. A new technique for the assay of infectivity of human adenovirus 5 DNA. Virology 52:456-467.

18. Grumont, R. J., and S. Gerondakis. 1989. Structure of a mammalian c-rel protein deduced from the nucleotide sequence of murine cDNA clones. Oncogene Res. 4:1-8.

19. Hirano, T., S. Akira, T. Taga, and T. Kishimoto. 1990. Biological and clinical aspects of interleukin 6. Immunol. Today 11:443-449.

20. Isshiki, H., S. Akira, O. Tanabe, T. Nakajima, T. Shimamoto, T. Hirano, and T. Kishimoto. 1990. Constitutive and interleukin-1 (IL-1)-inducible factors interact with the IL-1-responsive element in the IL-6 gene. Mol. Cell. Biol. 10:2757-2764.

21. Jonat, C., H. J. Rahmsdorf, K.-K. Park, A. C. B. Cato, S. Gebel, H. Ponta, and P. Herrlich. 1990. Antitumor promotion and antiinflammation: down-modulation of AP-1 (Fos/Jun) activity by glucocorticoid hormone. Cell 62:1189-1204.

22. Kawai, S., and M. Nishizawa. 1984. New procedure for DNA transfection with polycation and dimethyl sulfoxide. Mol. Cell. Biol. 4:1172-1174.

23. Kieran, M., V. Blank, F. Logeat, J. Vandekerckhove, F. Lottspeich, O. Le Bail, M. Urban, P. Kourilsky, P. A. Baeuerle, and A. Israël. 1990. The DNA binding subunit of NF- $k B$ is identical to factor KBF1 and homologous to the rel oncogene product. Cell 62:1007-1018.

24. Kristensen, M. S., K. Paludan, C. G. Larsen, C. O. C. Zachariae, B. W. Deleuran, P. K. A. Jensen, P. Jørgensen, and K. Thestrup-Pedersen. 1991. Quantitative determination of IL-1 $\alpha$ induced IL-8 mRNA levels in cultured human keratinocytes, dermal fibroblasts, endothelial cells, and monocytes. J. Invest. Dermatol. 97:506-510.

25. Kunsch, C., S. M. Ruben, and C. A. Rosen. 1992. Selection of optimal $\mathrm{\kappa B} / \mathrm{Rel}$ DNA-binding motifs: interaction of both subunits of NF-kB with DNA is required for transcriptional activa- 
tion. Mol. Cell. Biol. 12:4412-4421.

26. Li, X., and W. S.-L. Liao. 1991. Expression of rat serum amyloid Al gene involves both C/EBP-like and NF-кB-like transcription factors. J. Biol. Chem. 266:15192-15201.

27. Lucibello, F. C., E. P. Slater, K. U. Jooss, M. Beato, and R. Müller. 1990. Mutual transrepression of Fos and the glucocorticoid receptor: involvement of a functional domain in Fos that is absent from FosB. EMBO J. 9:2828-2834.

28. Matsushima, K., and J. J. Oppenheim. 1989. Interleukin 8 and MCAF: novel inflammatory cytokines inducible by IL 1 and TNF. Cytokine 1:2-13.

29. Mukaida, N., Y. Mahe, and K. Matsushima. 1990. Cooperative interaction of nuclear factor- $\mathrm{kB}$ and cis-regulatory enhancer binding protein-like factor binding elements in activating the interleukin-8 gene by pro-inflammatory cytokines. J. Biol. Chem. 265:21128-21133.

30. Mukaida, N., M. Shiroo, and K. Matsushima. 1989. Genomic structure of the human monocyte-derived neutrophil chemotactic factor IL-8. J. Immunol. 143:1366-1371.

31. Neri, A., C.-C. Chang, L. Lombardi, M. Salina, P. Corradini, A. T. Maiolo, R. S. K. Chaganti, and R. Dalla-Favera. 1991. B cell lymphoma-associated chromosomal translocation involves candidate oncogene $h y t-10$, homologous to NF-kB p50. Cell 67:1075-1087.

32. Neumann, J. R., C. A. Morency, and K. O. Russian. 1987. A novel rapid assay for chloramphenicol acetyltransferase gene expression. BioTechniques 5:444-448.

33. Nolan, G. P., S. Ghosh, H.-C. Liou, P. Tempst, and D. Baltimore. 1991. DNA binding and IKB inhibition of the cloned p65 subunit of NF-KB, a rel-related polypeptide. Cell 64:961-969.

34. Osborn, L., S. Kunkel, and G. J. Nabel. 1989. Tumor necrosis factor $\alpha$ and interleukin 1 stimulate the human immunodeficiency virus enhancer by activation of the nuclear factor $\mathrm{kB}$. Proc. Natl. Acad. Sci. USA 86:2336-2340.

35. Poli, V., and R. Cortese. 1989. Interleukin 6 induces a liverspecific nuclear protein that binds to the promoter of acutephase genes. Proc. Natl. Acad. Sci. USA 86:8202-8206.

36. Ruben, S. M., P. J. Dillon, R. Schreck, T. Henkel, C.-H. Chen,
M. Maher, P. A. Baeuerle, and C. A. Rosen. 1991. Isolation of a rel-related human cDNA that potentially encodes the $65-\mathrm{kD}$ subunit of NF-кB. Science 251:1490-1493.

37. Schmid, R. M., N. D. Perkins, C. S. Duckett, P. C. Andrews, and G. J. Nabel. 1991. Cloning of an NF-kB subunit which stimulates HIV transcription in synergy with p65. Nature (London) 352:733-736.

38. Schüle, R., P. Rangarajan, S. Kliewer, L. J. Ransone, J. Bolado, N. Yang, I. M. Verma, and R. M. Evans. 1990. Functional antagonism between oncoprotein c-Jun and the glucocorticoid receptor. Cell 62:1217-1226.

39. Stein, B., A. S. Baldwin, Jr., D. W. Ballard, W. C. Greene, P. Angel, and P. Herrlich. 1993. Cross-coupling of the NF-kB p65 and Fos/Jun transcription factors produces potentiated biological function. EMBO J. 12:3879-3891.

40. Stein, B., P. C. Cogswell, and A. S. Baldwin, Jr. 1993. Functional and physical associations between NF- $\mathrm{kB}$ and C/EBP family members: a Rel domain-bZIP interaction. Mol. Cell. Biol. 13:3964-3974.

41. Stein, B., H. J. Rahmsdorf, A. Stefien, M. Litfin, and P. Herrlich. 1989. UV-induced DNA damage is an intermediate in the UV-induced expression of human immunodeficiency virus type 1 , collagenase, c-fos, and metallothionein. Mol. Cell. Biol. 9:5169-5181

42. Van Snick, J. 1990. Interleukin-6: an overview. Annu. Rev. Immunol. 8:253-278.

43. Vinson, C. R., P. B. Sigler, and S. L. McKnight. 1989. Scissorsgrip model for DNA recognition by a family of leucine zipper proteins. Science 246:911-916.

44. Yang-Yen, H.-F., J.-C. Chambard, Y.-L. Sun, T. Smeal, T. J. Schmidt, J. Drouin, and M. Karin. 1990. Transcriptional interference between c-Jun and the glucocorticoid receptor: mutual inhibition of DNA binding due to direct protein-protein interaction. Cell 62:1205-1215.

45. Zachariae, C. O. C., K. Thestrup-Pedersen, and K. Matsushima. 1991. Expression and secretion of leukocyte chemotactic cytokines by normal human melanocytes and melanoma cells. J. Invest. Dermatol. 97:593-599. 